\title{
MENINGKATKAN PERKEMBANGAN SOSIAL ANAK MELALUI PENERAPAN MODEL PEMBELAJARAN KOOPERATIF TIPE JIGSAW PADA KELOMPOK B DI RA AL-HILAL (Penelitian Tindakan Kelas Pada Anak Usia 5 - 6 Tahun)
}

\author{
H. Suhada ${ }^{l}$ \\ Desy Apriani ${ }^{2}$ \\ Dosen AMIK Raharja Informatika ${ }^{1}$, Dosen STMIK Raharja ${ }^{2}$ \\ Jl. Jendral Sudirman No. 40, Modern Cikokol, Tangerang ${ }^{1,2}$ \\ Email : suhada@raharja.info ${ }^{1)}$, desy@raharja.info ${ }^{2)}$
}

\begin{abstract}
ABSTRAK
Meningkatkan Perkembangan Sosial Anak Melalui Penerapan Model Pembelajaran Kooperatif Tipe Jigsaw Pada Kelompok B di RA Al-Hilal (Penelitian Tindakan Kelas Pada anak Usia 5 - 6 Tahun). Penelitian ini dilatar belakangi adanya suatu permasalahan yang berhubungan dengan perkembangan sosial peserta didik yaitu kurang adanya rasa kebersamaan, saling memiliki, saling menyayangi antar teman, bersikap acuh tak acuh serta memudarnya rasa gotong royong diantara siswa satu dengan lainnya dikarenakan proses perubahan zaman yaitu era globalisasi yang mengkibatkan anak lebih mementingkan diri sendiri dan cenderung tidak peduli dengan lingkungan sekitar.Permasalahan yang diungkap dalam penelitian ini adalah bagaimanakah penerapan model pembelajaran kooperatif tipe jigsaw dapat meningkatkan perkembangan sosial anak pada Kelompok $B$ di RA Al-Hilal? Tujuanyang hendak dicapai dalam penelitian ini adalah untuk mengetahui peningkatan yang terjadi pada perkembangan sosial melalui penerapan model pembelajaran kooperatif pada Kelompok B di RA Al-Hilal Tahun ajaran 2016/ 2017.Penelitian ini merupakan Penelitian Tindakan Kelas. Subjek dalam penelitian ini adalah peserta didik Kelompok B di RAAlHilal, semester II Tahun ajaran 2016/2017 yang berjumlah 20 anak dengan komposisi laki-laki sejumlah 9 anak dan perempuan sejumlah 11 anak.Berdasarkan hasil analisis data penelitian setelah mendapatkan perlakuan menggunakan model pembelajaran kooperatif, menunjukkan adanya pengaruh positif dan signifikan dari perkembangan sosial anak pada Kelompok B di RA Al-Hilal Tahun ajaran 2016/2017. Skor peningkatan perkembangan sosial anak pada Kelompok B di RA AlHilal Tahun ajaran 2016/2017, kondisi awal diperoleh jumlah skor sebesar 242 poin (50,42\%) kemudian pada siklus I jumlah skor meningkat sebesar 89 poin $(18,26 \%)$ menjadi 331 poin $(68,68 \%)$, dan akhirnya pada siklus II jumlah skor meningkat sebesar 96 poin (20,15\%) menjadi 427 poin (88,83\%). Oleh karena itu, dapat disimpulkan bahwa penerapan model pembelajaran kooperatif terbukti dapat meningkatkan perkembangan sosial anak pada Kelompok B di RA Al-Hilal Tahun ajaran 2016/2017.
\end{abstract}

Kata kunci: Meningkatkan Perkembangan Sosial Anak, Penerapan Model Pembelajaran Kooperatif Tipe Jigsaw 


\begin{abstract}
Improving Social Development of Children through the Application of Cooperative Learning Model Jigsaw Type In Group B at RA Al-Hilal (Classroom Action Research In children aged 5-6 years). This research is based on the existence of a problem related to social development of learners that is lack of sense of togetherness, mutual ownership, mutual love among friends, being indifferent and waning mutual sense of mutual cooperation among students with each other due to the process of changing the era of globalization era Involving children are more self-interested and tend not to care about the environment.Problems revealed in this research is how the application of cooperative learning model of jigsaw type can improve social development of child in group B RAAl-Hilal? The goal to be achieved in this research is to know the improvement that happened in social development through applying cooperative learning model in group B RA Al-Hilal of academic year 2016/2017.This research is a Classroom Action Research. Subjects in this study were students of group B RA AlHilal, second semester of the academic year 2016/2017 which amounted to 20 children with the composition of men number of 9 children and women of 11 children. Based on result of analysis of research data after getting treatment using cooperative learning model, showing the positive and significant influence of social development of children in group $B$ RA Al-Hilal academic year 2016/2017. The score of improvement of social development of children in group B RA Al-Hilal The academic year 2016/2017, initial condition obtained the total score of 242 points (50.42\%) then in cycle I the number of scores increased by 89 points (18.26\%) to 331 Points (68.68\%), and finally in cycle II the number of scores increased by 96 points (20.15\%) to 427 points (88.83\%). Therefore, it can be concluded that the application of cooperative learning model proved to improve social development of children in group B RA Al-Hilal academic year 2016/2017.
\end{abstract}

Keywords: Improving Social Development of Children, The Application of Cooperative Learning Model Jigsaw Type

\title{
PENDAHULUAN
}

\section{Latar Belakang Masalah}

Pendidikan adalah salah satu faktor penting dalam kehidupan manusia. Melalui pendidikan, manusia mendapatkan suatu pengetahuan dan keterampilan baru untuk dikembangkan secara mandiri. Pendidikan pada umumnya adalah bimbingan atau arahan yang berwujud pengaruh yang diberikan oleh seseorang ke orang lain untuk mentransfer suatu pengetahuan, keterampilan, informasi, atau suatu ilmu baru. Secara teoretis dan filosofis tujuan pendidikan adalah membentuk pribadi peserta didik menjadi seorang dewasa yang berdiri sendiri dan tidak tergantung dengan orang lain.

Tujuan pendidikan nasional Indonesia yang tercantum dalam pasal 3 UU No. 20 Tahun 2003, menyatakan "Pendidikan nasional berfungsi mengembangkan kemampuan dan membentuk watak serta peradaban bangsa yang bermartabat dalam rangka mencerdaskan kehidupan bangsa, bertujuan untuk mengembangkan potensi peserta didik agar menjadi manusia yang beriman dan bertaqwa kepada Tuhan Yang Maha Esa, berakhlak mulia, sehat, berilmu, cakap, kreatif, mandiri, dan menjadi warga negara yang demokratis serta bertanggung jawab." Sedangkan menurut Depdiknas (2002) tujuan Pendidikan Anak Usia Dini adalah: (1) Membantu meletakkan dasar kearah perkembangan sikap, pengetahuan, 
keterampilan, dan daya cipta yang diperlukan anak dan (2) Menyiapkan anak untuk memasuki pendidikan dasar.

Menurut Permendiknas No. 137 Tahun 2014 tentang Standar Pendidikan Anak Usia Dini pencapaian perkembangan menggambarkan pertumbuhan dan perkembangan yang diharapkan dicapai anak pada rentang usia tertentu. Perkembangan anak yang dicapai merupakan integrasi aspek pemahaman nilai-nilai agama dan moral, fisik, kognitif, bahasa, dan sosial emosional.

Berdasarkan hasil pengamatan dan hasil penelitian di RA Al-Hilal Kelompok B Tahun ajaran 2016/ 2017. Terdapat suatu permasalahan yang berhubungan dengan perkembangan sosial peserta didik yaitu kurang adanya rasa kebersamaan, saling memiliki, saling menyayangi antar teman, lebih cenderung bersikap acuh tak acuh serta memudarnya rasa gotong royong diantara siswa satu dengan lainnya dikarenakan proses perubahan zaman yaitu era globalisasi yang mengakibatkan anak lebih mementingkan diri sendiri dan cenderung tidak peduli dengan lingkungan sekitar.

Berdasarkan latar belakang diatas maka peneliti melakukan suatu penelitian dengan judul " Meningkatkan Perkembangan Sosial Anak Melalui Penerapan Model Pembelajaran Kooperatif Tipe Jigsaw Pada Kelompok B RA Al-Hilal (Penelitian Tindakan Kelas Pada anak Usia 5-6 Tahun)"

\section{Fokus Masalah Penelitian}

Adapun fokus masalah dalam penelitian ini adalah penerapan model pembelajaran kooperatif tipe jigsaw untuk meningkatkan perkembangan sosial peserta didik pada kelompok B RA Al-Hilal.

\section{Perumusan Masalah}

Berdasarkan latar belakang, dan fokus penelitian di atas, diajukan rumusan masalah sebagai berikut:

1. Bagaimana perkembangan sosial anak pada RA Al-Hilal dapat ditingkatkan melalui penerapan model pembelajaran kooperatif tipe jigsaw?

2. Apakah dengan menggunakan penerapan model pembelajaran kooperatif tipe jigsaw dapat meningkatkan perkembangan sosial anak pada kelompok B RA AlHilal?

\section{Kajian Teori}

Batles (dalam Hildayani 2005: 1.3) menyatakan bahwa perkembangan berkaitan dengan perubahan-perubahan perilaku dalam diri seseorang sepanjang rentan kehidupannya, serta berkaitan dengan perbedaan dan kemiripan di antara orang-orang dalam sifat perubahan tersebut. Perkembangan merujuk kepada perubahan beraturan atau terpola mengikuti tahap 
atau sekuensi tertentu yang terjadi sepanjang siklus kehidupan manusia dan merupakan hasil dari berbagai proses biologis, kognitif, sosial dan moral (Satori, 2007: 3.3).

Lebih lanjut, perkembangan sosial menurut Suyanto (2005: 70) menggambarkan kemampuan anak untuk beradaptasi dengan lingkungan sosialnya secara efektif. Saputra dan Rudyanto (2005: 27) menyatakan "Perkembangan sosial merupakan pencapaian kematangan dalam hubungan sosial. Perkembangan sosial anak sangat dipengaruhi oleh proses perlakuan atau bimbingan orang."

Berdasarkan paparan di atas dapat disimpulkan bahwa perkembangan sosial anak adalah cara anak dalam menyesuaikan diri dengan lingkungan melalui perilaku khusus (unik) serta berperilaku sesuai dengan tuntutan nilai dan norma yang berlaku di lingkungan sekitarnya sehingga akan didapatkan suatu penerimaan sosial.

\section{Metode Penelitian}

Metode yang digunakan dalam penelitian ini adalah metode action research atau penelitian tindakan. Pada hakekatnya penelitian ini merupakan sebuah siklus dari sejak perencanaan (planning), pelaksanaan tindakan (acting), pengamatan (observing), dan refleksi. Sehubungan dengan tujuan untuk mengatasi suatu permasalahan yang terdapat di dalam kelas, maka metode yang digunakan dinamakan metode penelitian tindakan kelas (classroom action research).

Pemilihan metode ini dilatarbelakangi atas dasar analisis masalah dan tujuan penelitian yang memerlukan sejumlah informasi dan tindak lanjut yang terjadi di lapangan berdasarkan "daur ulang" yang menuntut kajian dan tindakan recara reflektif, kolaboratif, dan partisipatif. Oleh karena itu, maka penelitian ini merupakan penelitian tindakan yang dipusatkan pada situasi sosial kelas yang membutuhkan sejumlah informasi dan tindak lanjut secara langsung berdasarkan situasi alamiah yang terjadi dalam pelaksanaan pembelajaran.

Keabsahan data dilakukan untuk menyakinkan bahwa data yang diperoleh selama penelitian adalah benar dan valid, yaitu dengan menggunakan teknik triangulasi.

Teknik triangulasi, yaitu pemeriksaan keabsahan data yang memanfaatkan sesuatu yang lain di luar data untuk keperluan pengecekan atau sebagai pembanding terhadap data tersebut, dan teknik triangulasi yang paling banyak digunakan adalah dengan pemeriksaan melalui sumber yang lainnya.

Triangulasi dilakukan melalui wawancara, observasi langsung dan observasi tidak langsung. Observasi tidak langsung ini dimaksudkan dalam bentuk pengamatan atas beberapa kelakuan dan kejadian yang kemudian dari hasil pengamatan tersebut diambil benang merah yang menghubungkan di antara keduanya. 
Penelitian ini menggunakan triangulasi penyelidikan dengan cara memanfaatkan peneliti atau penguatan untuk pengecekan kembali kepercayaan data. Pemanfaatan pengamatan lainnya dalam hal ini adalah guru kelas kelompok B dan kepala sekolah RA AlHilal dapat membantu mengulangi kebenaran dalam pengumpulan data.

Analisis data yang dilakukan oleh peneliti pada penelitian ini dengan menggunakan rumus prosentase. Adapun rumusnya adalah sebagai berikut :

$\mathrm{P}=\frac{\mathrm{R}}{\mathrm{SM}} \times 100 \%$

Keterangan :

$\mathrm{P}=$ Angka prosentase

$\mathrm{R}=$ Jumlah Skor Perkategori

SM = Skor Maksimal (Arikunto, 2002:112)

Dengan klasifikasi tingkat keberhasilan sebagai berikut :

Tabel 3.4

Prosentase Analisa Data

\begin{tabular}{|c|c|}
\hline Prosentase & Keterangan \\
\hline$\leq 70 \%$ & Kurang \\
\hline $70 \%-79 \%$ & Sedang \\
\hline $80 \%-89 \%$ & Baik \\
\hline $90 \%-100 \%$ & Sangat baik \\
\hline
\end{tabular}

Perhitungan prosentase tersebut digunakan pada pengolahan data selanjutnya setelah dilaksanakan tindakan.

\section{Deskripsi Kondisi Awal}

Berdasarkan data hasil observasi dengan menggunakan lembar observasi kondisi awal sebelum dilakukan Penelitian Tindakan Kelas diperoleh keterangan bahwa skor perkembangan sosial anak kelompok B RA Al-Hilal sebesar 242 poin termasuk dalam kategori kurang dan tingkat ketercapaian indikator kinerja sebesar 50,42\%.

Aspek perkembangan sosial yang dimaksud meliputi: (a) Bersedia bermain dengan teman sebaya tanpa membedakan (warna kulit, keturunan, rambut, agama, dan lain-lain), (b) Mau memuji teman/ orang lain, (c) Mengajak teman untuk bermain, (d) Bermain bersama (permainan halma, ular tangga, dan lain-lain), (e) Berkomunikasi dengan temannya ketika mengalami sesuatu, (f) Bertanggung jawab terhadap tugas yang diberikan, (g) Bekerja sama dalam menyesaikan tugas, (h) Mengemukakan pendapat secara sederhana. Hasil lembar observasi mengenai perkembangan sosial anak tersaji dalam tabel berikut ini: 
Tabel 4.1

Rekapitulasi Perkembangan Sosial (Kondisi Awal)

\begin{tabular}{|c|c|c|c|c|c|c|c|}
\hline \multirow[t]{2}{*}{ No } & \multirow[t]{2}{*}{ Aspek yang Diamati } & \multicolumn{3}{|c|}{$\begin{array}{l}\text { Jumlah Peserta } \\
\text { Didik yang } \\
\text { Mendapat Skor }\end{array}$} & \multirow[t]{2}{*}{$\begin{array}{l}\text { Jumlah } \\
\text { Skor }\end{array}$} & \multirow[t]{2}{*}{ Persentase } & \multirow[t]{2}{*}{ Kategori } \\
\hline & & $\mathbf{K}$ & $\mathbf{C}$ & B & & & \\
\hline 1 & $\begin{array}{l}\text { Bersedia bermain dengan } \\
\text { teman sebaya tanpa } \\
\text { membedakan (warna } \\
\text { kulit, keturunan, rambut, } \\
\text { agama, dan lain-lain }\end{array}$ & 6 & 13 & 1 & 35 & 58 & Kurang \\
\hline 2 & $\begin{array}{l}\text { Mau memuji teman/ } \\
\text { orang lain }\end{array}$ & 15 & 3 & 2 & 27 & 45 & Kurang \\
\hline 3 & $\begin{array}{l}\text { Mengajak teman untuk } \\
\text { bermain }\end{array}$ & 11 & 8 & 1 & 30 & 50 & Kurang \\
\hline 4 & $\begin{array}{l}\text { Mampu berinteraksi } \\
\text { dalam bermain bersama }\end{array}$ & 8 & 12 & 0 & 32 & 53 & Kurang \\
\hline 5 & $\begin{array}{l}\text { Berkomunikasi dengan } \\
\text { temannya ketika bermain }\end{array}$ & 11 & 8 & 1 & 30 & 50 & Kurang \\
\hline 6 & $\begin{array}{l}\text { Bertanggung jawab } \\
\text { terhadap tugas yang } \\
\text { diberikan }\end{array}$ & 10 & 7 & 2 & 31 & 52 & Kurang \\
\hline 7 & $\begin{array}{l}\text { Bekerja sama dalam } \\
\text { menyesaikan tugas } \\
\text { (keterlibatan dalam } \\
\text { kelompok) }\end{array}$ & 13 & 7 & 0 & 27 & 45 & Kurang \\
\hline 8 & $\begin{array}{l}\text { Mengemukakan } \\
\text { pendapat secara } \\
\text { sederhana }\end{array}$ & 11 & 8 & 1 & 30 & 50 & Kurang \\
\hline & Jumlah & 85 & 66 & 8 & 242 & 403 & \\
\hline \multicolumn{5}{|c|}{ Rata-rata } & 30 & 50,42 & \\
\hline \multicolumn{5}{|c|}{ Persentase ketercapaian indikator } & \multicolumn{2}{|c|}{$50,42 \%$} & \\
\hline
\end{tabular}

Berdasarkan hasil observasi kemudian dilanjutkan dengan analisis data maka diperoleh data bahwa pada kondisi awal, perkembangan sosial anak termasuk dalam kategori kurang dengan persentase ketercapaian indikator kinerja sebesar 50,42\%.

\section{Deskripsi Siklus I}

Siklus I dilaksanakan 3 x pertemuan, pertemuan pertama dilaksanakan pada hari Selasa, 7 Maret 2017, pertemuan kedua pada hari Kamis, 9 Maret 2017 dan pertemuan ketiga pada hari Senin, 13 Maret 2017 selama 2 jam 30 menit. Pada siklus I peneliti menyampaikan materi pokok tentang tata cara bersosial di sekolah maupun di luar sekolah baik dengan sesama teman maupun guru dengan indikator: dapat berinteraksi dengan sesama teman sebaya maupun orang dewasa yang ada di sekitarnya.

Adapun kegiatan dilakukan selama proses pembelajaran siklus I meliputi tahap perencanaan, tindakan, pengamatan, dan refleksi diuraikan sebagai berikut: 
a. Perencanaan

Pada siklus I, perencanaan Penelitian Tindakan Kelas dimulai dari penyusunan Rencana Kegiatan Harian (RKH) yang memfokuskan pada materi pokok tentang tata cara bersosial di sekolah maupun di luar sekolah baik dengan sesama teman maupun guru dengan indikator: dapat berinteraksi dengan sesama teman sebaya maupun orang dewasa yang ada di sekitarnya.

Guru merancang desain model pembelajaran kooperatif tipe jigsaw dengan teknik mencari pasangan sebagai berikut:

Gambar 4.2

Desain Pembelajaran Kooperatif Tipe Jigsaw Siklus I

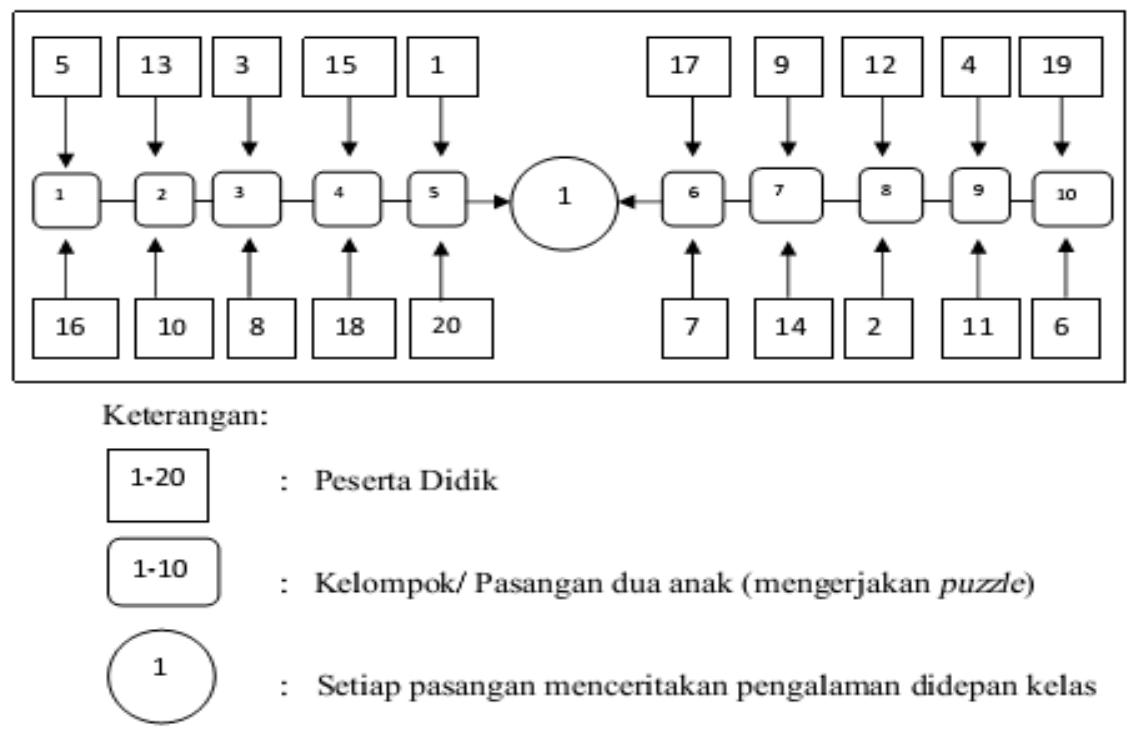

Peserta didik sejumlah 20 (dua puluh) anak dikelompokkan, setiap kelompok beranggotakan dua anak, cara pembentukan pasangan kelompok pada model pembelajaraan kooperatif ini menggunakan teknik mencari pasangan melalui kartu bergambar, setiap peserta didik memilih kartu bergambar dalam keadaan tertutup yang ada di tangan guru, setelah semua peserta didik mendapatkan kartu, peserta didik mencari pasangan sesuai dengan kartu bergambar yang didapatkannya, peserta didik yang mendapatkan gambar yang sesuai dengan peserta didik lain berarti mereka berpasangan, misal: gambar bantal berpasangan dengan guling, anak juga belajar memahami tentang konsep menghubungkan benda-benda yang sesuai pasangannya melalui kegiatan pencarian pasangan kelompok.

Setelah kelompok terbentuk, masing-masing peserta didik melaksanakan kegiatan dengan bermain puzzle bersama dengan pasangan kelompoknya, hal ini dapat meningkatkan interaksi antar peserta didik karena pada saat bermain bersama dengan pasangan kelompoknya akan terjalin komunikasi, rasa saling memiliki, kerja sama (gotong royong) untuk menyelesaikan tugas kelompok, mengemukakan pendapat secara sederhana dengan teman satu kelompoknya dan akhirnya perkembangan sosialnya akan meningkat karena setiap pertemuan mereka akan mendapat pasangan yang berbeda. Pada akhir kegiatan, guru mengajak peserta didik untuk berdiskusi tentang pengalaman apa yang didapatkannya setelah bermain bersama dengan temannya. Selanjutnya guru menyiapkan instrumen penelitian. 
Tabel 4.2

Kemampuan Perkembangan Sosial Anak

\begin{tabular}{|c|l|c|c|c|}
\hline \multirow{2}{*}{ No } & \multicolumn{2}{|c|}{ Aspek yang Diamati } & \multicolumn{2}{c|}{ Pilihan } \\
\cline { 2 - 5 } & \multicolumn{1}{|c|}{ K } & C & B \\
\hline 1 & $\begin{array}{l}\text { Bersedia bermain dengan teman sebaya } \\
\text { tanpa membedakan (warna kulit, } \\
\text { keturunan, rambut, agama, dan lain- } \\
\text { lain }\end{array}$ & & & \\
\hline 2 & Mau memuji teman/ orang lain & & & \\
\hline 3 & Mengajak teman untuk bermain & & & \\
\hline 4 & $\begin{array}{l}\text { Mampu berinteraksi dalam bermain } \\
\text { bersama }\end{array}$ & & & \\
\hline 5 & $\begin{array}{l}\text { Berkomunikasi dengan temannya } \\
\text { ketika bermain }\end{array}$ & & \\
\hline 6 & $\begin{array}{l}\text { Bertanggung jawab terhadap tugas } \\
\text { yang diberikan }\end{array}$ & & & \\
\hline 7 & $\begin{array}{l}\text { Bekerja sama dalam menyesaikan } \\
\text { tugas (keterlibatan dalam kelompok) }\end{array}$ & & & \\
\hline 8 & $\begin{array}{l}\text { Mengemukakan pendapat secara } \\
\text { sederhana }\end{array}$ & & & \\
\hline
\end{tabular}

$$
\begin{aligned}
& \text { Keterangan : } \\
& \mathrm{K}=\text { Kurang } \\
& \mathrm{C}=\text { Cukup } \\
& \mathrm{B}=\text { Baik }
\end{aligned}
$$

\section{b. Pelaksanaan}

Berpedoman pada Rencana Kegiatan Harian (RKH) yang telah disusun, guru melaksanakan siklus I yang memfokuskan pada materi pokok tentang tata cara bersosialisasi di sekolah maupun di luar sekolah baik dengan sesama teman maupun guru dengan indikator: dapat berinteraksi dengan sesama teman sebaya maupun orang dewasa yang ada di sekitarnya.

Guru mengawali proses pembelajaran dengan mengkondisikan peserta didik serta memberikan apersepsi/ pengantar berupa percakapan mengenai bagaimana tata cara hidup bersosial di sekolah untuk mengaitkan materi agar peserta didik siap untuk menerima materi. Setelah itu, guru memberikan arahan dalam pembelajaran kooperatif dengan teknik mencari pasangan melalui kartu bergambar (dua anak).

Langkah selanjutnya agar pembelajaran kooperatif dengan teknik mencari pasangan dapat berjalan, guru mengelompokkan peserta didik, masing-masing kelompok terdiri dari dua anak dengan cara peserta didik memilih kartu bergambar dalam keadaan tertutup yang ada di tangan guru.

Setelah masing-masing peserta didik mendapat kartu bergambar, langkah selanjutnya peserta didik mencari pasangan sesuai dengan kartu bergambar yang didapatkannya, peserta didik yang mendapatkan kartu bergambar sesuai dengan peserta didik lain berarti mereka berpasangan, misal: gambar bantal berpasangan dengan guling. Setelah kelompok terbentuk, masing-masing peserta didik melaksanakan kegiatan dengan bermain puzzle bersama dengan 
pasangan kelompoknya. Pada akhir kegiatan, guru mengajak peserta didik untuk berdiskusi tentang pengalaman apa yang didapatkannya setelah bermain bersama dengan temannya.

\section{c. Observasi}

Observasi dilakukan dengan melibatkan teman sejawat/ Kepala Sekolah dengan menggunakan lembar observasi. Aspek yang diobservasi yaitu tentang kemampuan perkembangan sosial anak. Hasil lembar observasi siklus I mengenai perkembangan sosial anak tersaji dalam tabel berikut ini:

Tabel 4.3

Rekapitulasi Hasil Observasi Perkembangan Sosial (Siklus I)

\begin{tabular}{|c|c|c|c|c|c|c|c|}
\hline \multirow[t]{2}{*}{ No } & \multirow[t]{2}{*}{ Aspek yang Diamati } & \multicolumn{3}{|c|}{$\begin{array}{l}\text { Jumlah Peserta } \\
\text { Didik yang } \\
\text { Mendapat Skor }\end{array}$} & \multirow[t]{2}{*}{$\begin{array}{c}\text { Jumlah } \\
\text { Skor }\end{array}$} & \multirow[t]{2}{*}{ Persentase } & \multirow[t]{2}{*}{ Kategori } \\
\hline & & $\mathbf{K}$ & $\mathrm{C}$ & B & & & \\
\hline 1 & $\begin{array}{l}\text { Bersedia bermain dengan } \\
\text { teman sebaya tanpa } \\
\text { membedakan (warna } \\
\text { kulit, keturunan, rambut, } \\
\text { agama, dan lain-lain }\end{array}$ & 0 & 16 & 4 & 44 & 73 & Cukup \\
\hline 2 & $\begin{array}{l}\text { Mau memuji teman/ } \\
\text { orang lain }\end{array}$ & 3 & 15 & 2 & 39 & 64 & Kurang \\
\hline 3 & $\begin{array}{l}\text { Mengajak teman untuk } \\
\text { bermain }\end{array}$ & 4 & 14 & 2 & 38 & 64 & Kurang \\
\hline 4 & $\begin{array}{l}\text { Mampu berinteraksi } \\
\text { dalam bermain bersama }\end{array}$ & 2 & 12 & 6 & 44 & 73 & Cukup \\
\hline 5 & $\begin{array}{l}\text { Berkomunikasi dengan } \\
\text { temannya ketika bermain }\end{array}$ & 2 & 15 & 3 & 41 & 69 & Cukup \\
\hline 6 & $\begin{array}{l}\text { Bertanggung jawab } \\
\text { terhadap tugas yang } \\
\text { diberikan }\end{array}$ & 0 & 17 & 3 & 43 & 72 & Cukup \\
\hline 7 & $\begin{array}{l}\text { Bekerja sama dalam } \\
\text { menyesaikan tugas } \\
\text { (keterlibatan dalam } \\
\text { kelompok) }\end{array}$ & 0 & 16 & 4 & 44 & 73 & Cukup \\
\hline 8 & $\begin{array}{l}\text { Mengemukakan endapat } \\
\text { secara sederhana }\end{array}$ & 4 & 14 & 2 & 38 & 63 & Kurang \\
\hline \multirow{2}{*}{\multicolumn{5}{|c|}{ Rata-rata }} & 331 & 551 & \\
\hline & & & & & 41 & $68,68 \%$ & \\
\hline \multicolumn{5}{|c|}{ Persentase ketercapaian indikator } & \multicolumn{2}{|c|}{$68,68 \%$} & \\
\hline
\end{tabular}

Keterangan :

$\mathrm{K}=$ Kurang

C $=$ Cukup

$\mathrm{B}=$ Baik

Berdasarkan tabel di atas didapat bahwa didapat hasil penilaian terhadap siswa Pada aspek yang diamati pertama yaitu tentang bersedia bermain dengan teman sebaya tanpa membedakan (warna kulit, keturunan, rambut, 
agama, dan lain-lain“ didapat siswa yang masuk dalam kategori penilaian kurang tidak ada, yang masuk dalam kategori penilaian cukup sebanyak 16 orang, dan yang masuk dalam kategori penilaian baik sebanyak 4 orang.

Pada aspek yang diamati kedua yaitu tentang "Mau memuji teman/ orang lain" didapat siswa yang masuk dalam kategori penilaian kurang sebanyak 3 orang, yang masuk dalam kategori penilaian cukup sebanyak 15 orang, dan yang masuk dalam kategori penilaian baik sebanyak 2 orang.

Pada aspek yang diamati ketiga yaitu tentang "mengajak teman untuk bermain " didapat siswa yang masuk dalam kategori penilaian kurang sebanyak 4 orang, yang masuk dalam kategori penilaian cukup sebanyak 14 orang, dan yang masuk dalam kategori penilaian baik sebanyak 2 orang.

Pada aspek yang diamati keempat yaitu tentang "mampu berinteraksi dalam bermain bersama" didapat siswa yang masuk dalam kategori penilaian kurang tidak ada, yang masuk dalam kategori penilaian cukup sebanyak 12 orang, dan yang masuk dalam kategori penilaian baik sebanyak 6 orang.

Pada aspek yang diamati kelima yaitu tentang "berkomunikasi dengan temannya ketika bermain" didapat siswa yang masuk dalam kategori penilaian kurang sebanyak 2 orang, yang masuk dalam kategori penilaian cukup sebanyak 15 orang, dan yang masuk dalam kategori penilaian baik sebanyak 3 orang.

Pada aspek yang diamati keenam yaitu tentang "bertanggung jawab terhadap tugas yang diberikan" didapat siswa yang masuk dalam kategori penilaian kurang sebanyak tidak ada, yang masuk dalam kategori penilaian cukup sebanyak 17 orang, dan yang masuk dalam kategori penilaian baik sebanyak 3 orang.

Pada aspek yang diamati ketujuh yaitu tentang "bekerja sama dalam menyesaikan tugas (keterlibatan dalam kelompok)“ didapat siswa yang masuk dalam kategori penilaian kurang sebanyak tidak ada, yang masuk dalam kategori penilaian cukup sebanyak 16 orang, dan yang masuk dalam kategori penilaian baik sebanyak 4 orang.

Pada aspek yang diamati kedelapan yaitu tentang "mengemukakan endapat secara sederhana" didapat siswa yang masuk dalam kategori penilaian kurang sebanyak 4 orang, yang masuk dalam kategori penilaian cukup sebanyak 14 orang, dan yang masuk dalam kategori penilaian baik sebanyak 2 orang.

Berdasarkan rekapitulasi hasil observasi perkembangan sosial anak setelah pelaksanaan pembelajaran kooperatif tipe jigsaw pada siklus I, diperoleh data jumlah skor sebesar 331 poin dengan persentase ketercapaian indikator $68,68 \%$, sehingga indikator kinerja yang mensyaratkan $80 \%$ peserta didik meningkat perkembangan sosialnya setelah mengikuti pembelajaran kooperatif tipe jigsaw yang ditandai dengan aktivitas siswa minimal baik dalam lembar observasi, dikatakan belum berhasil secara maksimal.

d. Refleksi

Tahapan setelah pengamatan (observing) adalah (reflecting), refleksi yang berupa koreksi terhadap tindakan yang telah dilaksanakan ini dilakukan untuk mengetahui 
kekurangan yang ada pada siklus I. Kekurangan siklus I yaitu masih terdapat peserta didik yang belum memahami pembelajaran menggunakan model pembelajaran kooperatif tipe jigsaw dengan teknik mencari pasangan, serta pembagian kelompok dengan dua anggota kurang berhasil secara maksimal untuk meningkatkan interaksi antar siswa. Hal tersebut dapat dilihat dari skor hasil observasi kemampuan perkembangan sosial setelah mengikuti proses pembelajaran kooperatif dengan teknik mencari pasangan (dua anak) sebesar 331 poin dengan persentase ketercapaian indikator baru mencapai 68,68\%, sehingga belum mencapai indikator keberhasilan dalam penelitian tindakan kelas ini.

Indikator keberhasilan dalam penelitian ini yaitu $80 \%$ peserta didik mengalami peningkatan dalam perkembangan sosial setelah mengikuti proses pembelajaran menggunakan model pembelajaran kooperatif tipe jigsaw yang ditandai dengan aktivitas siswa minimal baik dalam lembar observasi.

Berdasarkan hasil refleksi pada siklus I maka dapat disimpulkan bahwa perlu dilaksanakan siklus II agar indikator kinerja dapat tercapai.

\section{Deskripsi Siklus II}

Siklus II dilaksanakan $3 \mathrm{x}$ pertemuan, pertemuan pertama dilaksanakan pada hari Selasa, 14 Maret 2017, pertemuan kedua pada hari Jum'at, 17 Maret 2017 dan pertemuan ketiga pada hari Senin 20 Maret 2017 selama 2 jam 30 menit. Pada siklus II peneliti menyampaikan materi pokok tentang tata cara bersosial di sekolah maupun di luar sekolah baik dengan sesama teman maupun guru dengan indikator: dapat berinteraksi dengan teman sebaya maupun orang dewasa yang ada di sekitarnya, tetapi untuk siklus II lebih berfokus pada interaksi peserta didik dengan semua teman yang ada kelas.

Adapun kegiatan dilakukan selama proses pembelajaran siklus I meliputi tahap perencanaan, tindakan, pengamatan, dan refleksi diuraikan sebagai berikut:

\section{a. Perencanaan}

Berpedoman pada refleksi siklus I, perencanaan penelitian tindakan kelas pada siklus II diupayakan mengantisipasi berbagai kelemahan sebelumnya. Pada siklus II, perencanaan Penelitian Tindakan Kelas dimulai dari penyusunan Rencana Kegiatan Harian (RKH) yang memfokuskan pada materi pokok tentang tata cara bersosial di sekolah maupun di luar sekolah baik dengan sesama teman maupun guru dengan indikator: dapat berinteraksi dengan teman sebaya maupun orang dewasa yang ada di sekitarnya.

Guru merancang desain model pembelajaran kooperatif tipe jigsaw dengan teknik mencari pasangan sebagai berikut: 
Gambar 4.2

Desain Pembelajaran Kooperatif Siklus II

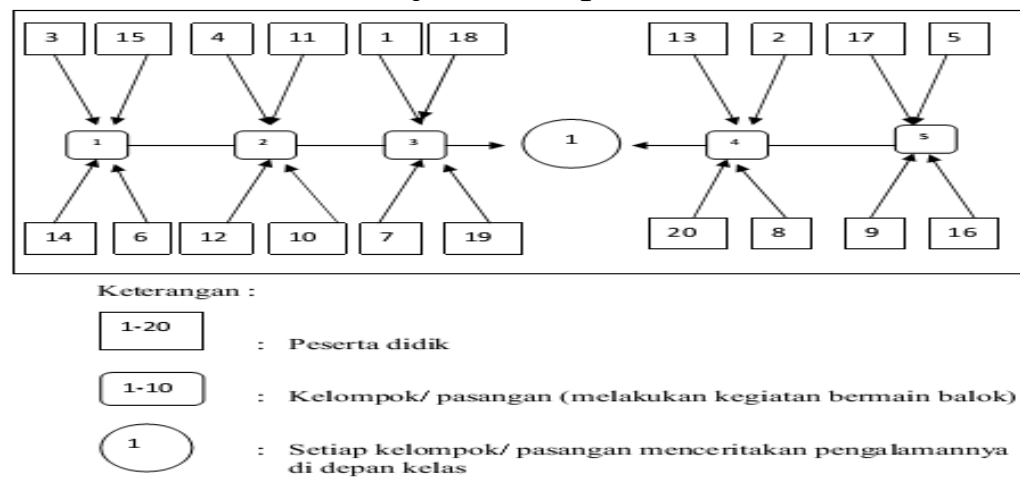

Peserta didik sejumlah 20 (dua puluh) anak dikelompokkan, setiap kelompok beranggotakan empat anak, jumlah anggota kelompok sebanyak empat anak dimaksudkan agar interaksi antar peserta didik dengan teman satu kelas dapat lebih meningkat dibandingkan siklus I karena anak akan lebih banyak berinteraksi dengan banyak teman, cara pembentukan kelompok pada model pembelajaraan kooperatif ini menggunakan teknik mencari pasangan melalui kartu bergambar, setiap peserta didik memilih kartu bergambar dalam keadaan tertutup yang ada di tangan guru, setelah semua peserta didik mendapatkan kartu, peserta didik mencari pasangan sesuai dengan kartu bergambar yang didapatkannya, peserta didik yang mendapatkan kartu bergambar yang sesuai dengan peserta didik lain berarti mereka berpasangan, misal: gambar sapi berpasangan dengan gambar kerbau, ayam dan kambing karena empat kartu tersebut masuk dalam kategori binatang, anak juga belajar memahami tentang konsep menggelompokkan benda berdasarkan jenisnya melalui kegiatan mencari pasangan dalam kelompok.

Setelah kelompok terbentuk, guru memberikan penjelasan tentang tema penyusunan balok dan peraturan permainan serta memperagakan berbagai sikap menjalin hubungan baik dengan teman atau anggota kelompok, masing-masing kelompok dipimpin oleh seorang ketua, selanjutnya anak melaksanakan kegiatan dengan bermain balok bersama dengan teman satu kelompoknya, setiap kelompok didorong untuk membuat berbagai bentuk susunan balok yang sudah disepakati oleh kelompoknya, hal ini dapat meningkatkan interaksi antar peserta didik karena pada saat bermain dengan teman satu kelompoknya akan terjalin komunikasi, rasa saling memiliki, kerja sama (gotong royong) untuk menyelesaikan tugas kelompok, mengemukakan pendapat secara sederhana dengan teman satu kelompoknya dan akhirnya perkembangan sosialnya akan meningkat karena setiap pertemuan mereka akan mendapatkan teman satu kelompok yang berbeda.

Setelah selesai menyusun bangunan dari balok, kemudian setiap kelompok menceritakan apa yang telah disusun dari kegiatan bermain balok. Pada akhir kegiatan, guru memberikan evaluasi serta mengajak peserta didik untuk berdiskusi tentang pengalaman apa yang didapatkannya setelah bermain bersama dengan temannya. Guru menyiapkan instrumen penelitian. 
Tabel 4.4

Kemampuan Perkembangan Sosial Anak

\begin{tabular}{|c|l|c|c|c|}
\hline \multirow{2}{*}{ No } & \multicolumn{1}{|c|}{ Aspek yang Diamati } & \multicolumn{2}{c|}{ Pilihan } \\
\cline { 3 - 5 } & \multicolumn{1}{|c|}{$\begin{array}{l}\text { K } \\
\text { Bersedia bermain dengan teman } \\
\text { sebaya tanpa membedakan } \\
\text { (warna kulit, keturunan, rambut, } \\
\text { agama, dan lain-lain }\end{array}$} & & & \\
\hline 2 & Mau memuji teman/ orang lain & & & \\
\hline 3 & Mengajak teman untuk bermain & & & \\
\hline 4 & $\begin{array}{l}\text { Mampu berinteraksi dalam } \\
\text { bermain bersama }\end{array}$ & & \\
\hline 5 & $\begin{array}{l}\text { Berkomunikasi dengan temannya } \\
\text { ketika bermain }\end{array}$ & & & \\
\hline 6 & $\begin{array}{l}\text { Bertanggung jawab terhadap } \\
\text { tugas yang diberikan }\end{array}$ & & \\
\hline 7 & $\begin{array}{l}\text { Bekerja sama dalam } \\
\text { menyesaikan tugas (keterlibatan } \\
\text { dalam kelompok) }\end{array}$ & & & \\
\hline 8 & $\begin{array}{l}\text { Mengemukakan pendapat secara } \\
\text { sederhana }\end{array}$ & & & \\
\hline
\end{tabular}

Keterangan :

$\mathrm{K}=$ Kurang

$\mathrm{C}=$ Cukup

$\mathrm{B}=$ Baik

\section{b. Pelaksanaan}

Berpedoman pada Rencana Kegiatan Harian (RKH) yang telah disusun, guru melaksanakan siklus II yang memfokuskan pada materi pokok tentang tata cara bersosialisasi di sekolah maupun di luar sekolah baik dengan sesama teman maupun guru dengan indikator: dapat berinteraksi dengan sesama teman sebaya maupun orang dewasa yang ada di sekitarnya.

Guru mengawali proses pembelajaran dengan mengkondisikan peserta didik dengan berbagai permainan, gerak lagu dan tepuk agar peserta didik lebih bersemangat dalam mengikuti proses pembelajaran, selanjutnya guru memberikan apersepsi/ pengantar berupa percakapan mengenai bagaimana tata cara hidup bersosial di sekolah untuk mengaitkan materi agar peserta didik siap untuk menerima materi. Setelah itu, guru memberikan arahan dalam pembelajaran kooperatif dengan teknik mencari pasangan melalui kartu bergambar (empat anak).

Untuk mengaitkan materi agar peserta didik siap untuk menerima materi. Setelah itu, guru memberikan arahan dalam pembelajaran kooperatif dengan teknik mencari pasangan melalui kartu bergambar (empat anak).

Langkah selanjutnya agar pembelajaran kooperatif dengan teknik mencari pasangan dapat berjalan, guru mengelompokkan peserta didik, masing-masing kelompok terdiri dari empat anak dengan cara peserta didik memilih kartu bergambar dalam keadaan tertutup yang ada di tangan guru. Setelah masing-masing anak mendapatkan kartu bergambar, langkah 
selanjutnya anak mencari pasangan sesuai dengan kartu bergambar yang didapatkannya, anak yang mendapatkan kartu bergambar yang sesuai dengan anak lain berarti mereka berpasangan, misal: gambar sapi berpasangan dengan gambar kerbau, ayam dan kambing karena empat gambar dalam kartu tersebut termasuk dalam kategori binatang.

Setelah kelompok terbentuk, guru memberikan penjelasan tentang tema penyusunan balok dan peraturan permainan serta memperagakan berbagai sikap menjalin hubungan baik dengan teman atau anggota kelompok, masing-masing kelompok dipimpin oleh seorang ketua, selanjutnya anak melaksanakan kegiatan dengan bermain balok bersama dengan pasangan satu kelompoknya, setiap kelompok didorong untuk membuat berbagai bentuk susunan balok yang sudah disepakati oleh kelompoknya. Setelah selesai menyusun bangunan dari balok, kemudian setiap kelompok menceritakan apa yang telah disusun dari kegiatan bermain balok. Pada akhir kegiatan, guru memberikan evaluasi serta mengajak peserta didik untuk berdiskusi tentang pengalaman apa yang didapatkannya setelah bermain bersama dengan temannya.

\section{c. Observasi}

Observasi dilakukan dengan melibatkan teman sejawat/ Kepala Sekolah dengan menggunakan lembar observasi. Aspek yang diobservasi yaitu tentang kemampuan perkembangan sosial. Hasil lembar observasi siklus II mengenai perkembangan sosial anak tersaji dalam tabel berikut ini:

Tabel 4.5

Rekapitulasi Hasil Observasi Perkembangan Sosial (Siklus II)

\begin{tabular}{|c|l|c|c|c|c|c|l|}
\hline \multirow{2}{*}{ No } & Aspek yang Diamati & \multicolumn{2}{|c|}{$\begin{array}{l}\text { Jumlah Peserta } \\
\text { Didik yang } \\
\text { Mendapat Skor }\end{array}$} & $\begin{array}{c}\text { Jumlah } \\
\text { Skor }\end{array}$ & Persentase & Kategori \\
\cline { 2 - 6 } & K & C & B & & & \\
\hline 1 & $\begin{array}{l}\text { Bersedia bermain } \\
\text { dengan teman sebaya } \\
\text { tanpa membedakan } \\
\text { (warna kulit, } \\
\text { keturunan, rambut, } \\
\text { agama, dan lain-lain }\end{array}$ & 0 & 5 & 15 & 55 & 91 & Baik \\
\hline 2 & $\begin{array}{l}\text { Mau memuji teman/ } \\
\text { orang lain }\end{array}$ & 1 & 8 & 11 & 50 & 83 & Baik \\
\hline 3 & $\begin{array}{l}\text { Mengajak teman } \\
\text { untuk bermain }\end{array}$ & 0 & 5 & 15 & 55 & 91 & Baik \\
\hline 4 & $\begin{array}{l}\text { Mampu berinteraksi } \\
\text { dalam bermain } \\
\text { bersama }\end{array}$ & 0 & 3 & 17 & 57 & 95 & Baik \\
\hline
\end{tabular}




\begin{tabular}{|c|c|c|c|c|c|c|c|}
\hline 5 & $\begin{array}{l}\text { Berkomunikasi } \\
\text { dengan temannya } \\
\text { ketika bermain }\end{array}$ & 0 & 5 & 15 & 55 & 91 & Baik \\
\hline 6 & $\begin{array}{l}\text { Bertanggung jawab } \\
\text { terhadap tugas yang } \\
\text { diberikan }\end{array}$ & 0 & 7 & 13 & 53 & 88 & Baik \\
\hline 7 & $\begin{array}{l}\text { Bekerja sama dalam } \\
\text { menyesaikan tugas } \\
\text { (keterlibatan dalam } \\
\text { kelompok) }\end{array}$ & 0 & 5 & 15 & 55 & 91 & Baik \\
\hline 8 & $\begin{array}{l}\text { Mengemukakan } \\
\text { endapat secara } \\
\text { sederhana }\end{array}$ & 2 & 9 & 9 & 47 & 78 & Cukup \\
\hline & Jumlah & 3 & 47 & 110 & 427 & 708 & \\
\hline \multicolumn{5}{|c|}{ Rata-rata } & 53 & 88,83 & \\
\hline \multicolumn{5}{|c|}{ Persentase ketercapaian indikator } & \multicolumn{2}{|c|}{$88,83 \%$} & \\
\hline
\end{tabular}

\footnotetext{
Keterangan :

$\mathrm{K}=$ Kurang

$\mathrm{C}=$ Cukup

$\mathrm{B}=$ Baik
}

Berdasarkan tabel di atas didapat bahwa didapat hasil penilaian terhadap siswa Pada aspek yang diamati pertama yaitu tentang bersedia bermain dengan teman sebaya tanpa membedakan (warna kulit, keturunan, rambut, agama, dan lain-lain“ didapat siswa yang masuk dalam kategori penilaian kurang tidak ada, yang masuk dalam kategori penilaian cukup sebanyak 5 orang, dan yang masuk dalam kategori penilaian baik sebanyak 15 orang.

Pada aspek yang diamati kedua yaitu tentang "mau memuji teman/ orang lain" didapat siswa yang masuk dalam kategori penilaian kurang sebanyak 1 orang, yang masuk dalam kategori penilaian cukup sebanyak 8 orang, dan yang masuk dalam kategori penilaian baik sebanyak 11 orang.

Pada aspek yang diamati ketiga yaitu tentang "mengajak teman untuk bermain " didapat siswa yang masuk dalam kategori penilaian kurang tidak ada, yang masuk dalam kategori penilaian cukup sebanyak 5 orang, dan yang masuk dalam kategori penilaian baik sebanyak 15 orang.

Pada aspek yang diamati keempat yaitu tentang "mampu berinteraksi dalam bermain bersama" didapat siswa yang masuk dalam kategori penilaian kurang tidak ada, yang masuk dalam kategori penilaian cukup sebanyak 3 orang, dan yang masuk dalam kategori penilaian baik sebanyak 17 orang.

Pada aspek yang diamati kelima yaitu tentang "berkomunikasi dengan temannya ketika bermain" didapat siswa yang masuk dalam kategori penilaian kurang tidak ada, yang masuk 
dalam kategori penilaian cukup sebanyak 5 orang, dan yang masuk dalam kategori penilaian baik sebanyak 15 orang.

Pada aspek yang diamati keenam yaitu tentang "bertanggung jawab terhadap tugas yang diberikan" didapat siswa yang masuk dalam kategori penilaian kurang sebanyak tidak ada, yang masuk dalam kategori penilaian cukup sebanyak 7 orang, dan yang masuk dalam kategori penilaian baik sebanyak 13 orang.

Pada aspek yang diamati ketujuh yaitu tentang "bekerja sama dalam menyesaikan tugas (keterlibatan dalam kelompok)" didapat siswa yang masuk dalam kategori penilaian kurang sebanyak tidak ada, yang masuk dalam kategori penilaian cukup sebanyak 5 orang, dan yang masuk dalam kategori penilaian baik sebanyak 15 orang.

Pada aspek yang diamati kedelapan yaitu tentang "mengemukakan pendapat secara sederhana" didapat siswa yang masuk dalam kategori penilaian kurang sebanyak 2 orang, yang masuk dalam kategori penilaian cukup sebanyak 9 orang, dan yang masuk dalam kategori penilaian baik sebanyak 9 orang.

Berdasarkan rekapitulasi hasil observasi perkembangan sosial anak setelah pelaksanaan pembelajaran kooperatif dengan teknik mencari pasangan (empat anak) pada siklus II, diperoleh data jumlah skor sebesar 427 poin dengan persentase ketercapaian indikator $88,83 \%$, sehingga indikator kinerja yang mensyaratkan $80 \%$ peserta didik meningkat perkembangan sosialnya setelah mengikuti pembelajaran kooperatif yang ditandai dengan aktivitas siswa minimal baik dalan lembar observasi, sudah berhasil sehingga tidak diperlukan lagi siklus selanjutnya.

\section{d. Refleksi}

Berdasarkan pelaksanaan siklus II, maka peneliti melakukan kegiatan refleksi berupa koreksi terhadap tindakan yang telah dilaksanakan, hal ini dilakukan untuk mengetahui kekurangan yang ada pada siklus II, siswa sudah dapat memahami proses pembelajaran menggunakan model kooperatif dengan teknik mencari pasangan, hal tersebut ditandai dengan meningkatnya aktivitas siswa pada siklus II. Pembagian kelompok dengan anggota kelompok empat anak juga berhasil meningkatkan interaksi antar siswa.

Berdasarkan analisis data hasil observasi yang dilakukan diakhir siklus pada siklus II, peningkatan perkembangan sosial anak mencapai $88,83 \%$ dengan perolehan jumlah skor sebesar 427 poin, sehingga sudah mencapai indikator keberhasilan dalam penelitian ini. Pada siklus II skor dan persentase sudah memenuhi indikator keberhasilan dalam Penelitian Tindakan Kelas ini, sehingga tidak diperlukan lagi siklus selanjutnya.

Berarti hasil penelitian tentang perkembangan sosial anak melalui penerapan model pembelajaran koopeatif tipe jigsaw pada kelompok B RA Al-Hilal dikatakan ada peningkatan dan berhasil. Hal ini dapat dilihat dari hasil yang didapat ada peningkatan antara kegiatan siklus I dan siklus II. 


\section{PEMBAHASAN}

Berdasarkan hasil penelitian pada siklus I dan II menunjukkan bahwa penerapan model pembelajaran kooperatif tipe jigsaw dapat meningkatkan perkembangan sosial anak RA AlHilal. Hal ini terlihat dari pengamatan yang dilakukan oleh peneliti dan kolaborator terhadap peningkatan perkembangan sosial anak pada siklus II yang mengalami peningkatan dari siklus I.

Pada siklus I, perkembangan sosial melalui model pembelajaran kooperatif tipe jigsaw belum menunjukkan hasil yang maksimal. Pada siklus I hanya diperoleh jumlah skor sebesar 331 poin dengan persentase ketercapaian indikator $68,68 \%$. Berdasarkan hasil tersebut maka siklus I masih belum mencapai indikator kinerja yang diharapkan.

Pada siklus II, perkembangan sosial melalui model pembelajaran kooperatif tipe jigsaw sudah menunjukkan hasil yang maksimal. Hal tersebut terbukti dari perolehan jumlah skor sebesar 427 poin dengan persentase ketercapaian indikator 88,83\%. Berdasarkan hasil tersebut maka siklus II sudah mencapai indikator kinerja yang diharapkan.

Peningkatan hasil observasi (perkembangan sosial) Kondisi awal, Siklus I dan Siklus II, tersaji dalam tabel berikut ini:

Tabel 4.6

Peningkatan Perkembangan Sosial Kondisi Awal, Siklus I dan Siklus II

\begin{tabular}{|l|c|c|c|}
\hline \multicolumn{1}{|c|}{ Hasil Penelitian } & $\begin{array}{c}\text { Kondisi } \\
\text { Awal }\end{array}$ & Siklus I & Siklus II \\
\hline $\begin{array}{l}\text { Rata-rata hasil observasi } \\
\text { (Perkembangan sosial) }\end{array}$ & 50,42 & 68,68 & 88,83 \\
\hline Ketercapaian Indikator & $50,42 \%$ & $68,68 \%$ & $88,83 \%$ \\
\hline
\end{tabular}

Berdasarkan tabel di atas perubahan sikap perilaku anak pada Kondisi Awal, Siklus I dan Siklus II dapat digambarkan dengan grafik berikut ini:

Gambar 4.3

Grafik Peningkatan Perkembangan Sosial Kondisi Awal, Siklus I dan Siklus II

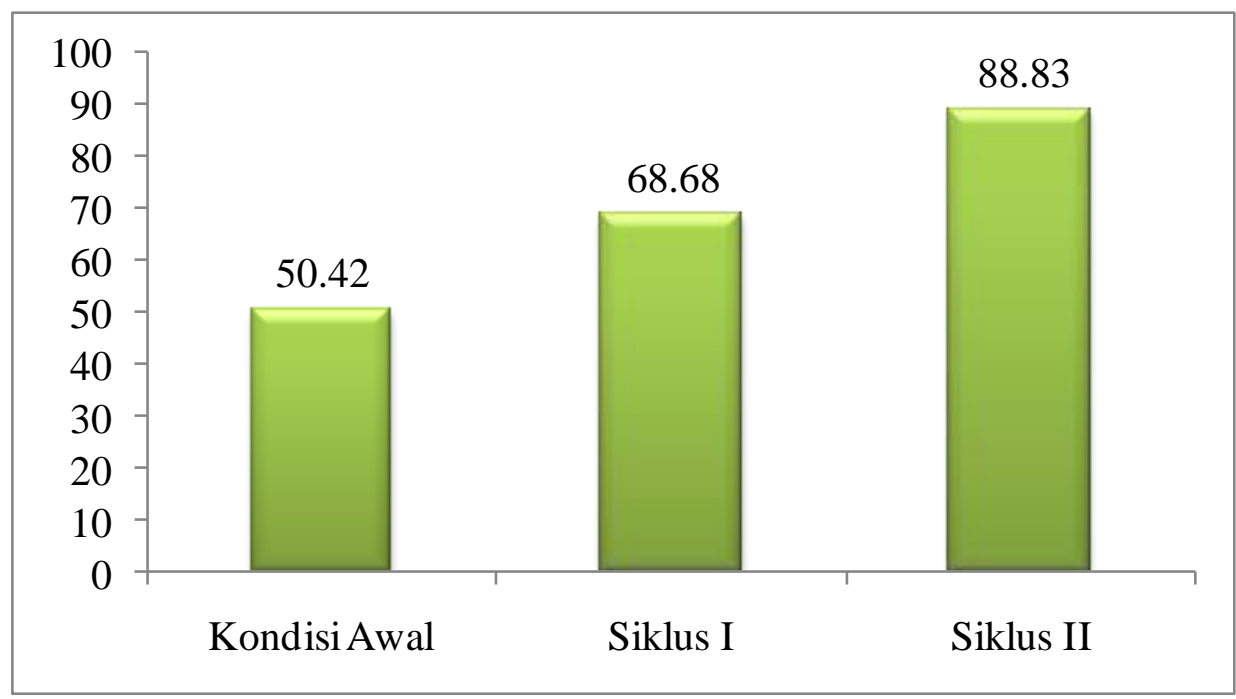


Berdasarkan hasil penelitian dapat disimpulkan bahwa hipotesis tindakan yang berbunyi melalui Penerapan Model pembelajaran kooperatif tipe jigsaw dapat Meningkatkan Perkembangan Sosial Anak pada Kelompok B RA Al- Hilal, dapat diterima kebenarannya.

\section{KESIMPULAN}

Berdasarkan hasil Penelitian Tindakan Kelas dapat disimpulkan bahwa penerapan model pembelajaran kooperatif terbukti dapat meningkatkan perkembangan sosial anak pada kelompok B RA Al-Hilal. Hal tersebut ditandai dengan peningkatan skor dan persentase hasil observasi perubahan sikap perilaku peserta didik.

Skor peningkatan perkembangan sosial anak kelompok B RA Al-Hilal, kondisi awal diperoleh jumlah skor sebesar 242 poin $(50,42 \%)$ kemudian pada siklus I, jumlah skor meningkat sebesar 89 poin $(18,26 \%)$ menjadi 331 poin $(68,68 \%)$, dan akhirnya pada siklus II jumlah skor meningkat sebesar 96 poin $(20,15 \%)$ menjadi 427 poin $(88,83 \%)$.

Berdasarkan hasil analisis tersebut dapat disimpulkan bahwa hipotesis penelitian yang berbunyi melalui Penerapan Model Pembelajaran Kooperatif dapat Meningkatkan Perkembangan Sosial Anak pada Kelompok B RA Al-Hilal, dapat diterima kebenarannya.

\section{DAFTAR PUSTAKA}

[1] Depdiknas. 2006. Perilaku Sosial Anak. Jakarta: Depdiknas.

[2] Depdiknas. 2009. Kurikulum Tingkat Satuan Pendidikan. Jakarta: Depdiknas.

[3] Isjoni. 2012. Pembelajaran Kooperatif Meningkatkan Kecerdasan Komunikasi Antar Peserta Didik. Yogyakarta: Pustaka Pelajar.

[4] Morrison, George S. 2012. Dasar-Dasar Pendidikan Anak Usia Dini (PAUD). Jakarta: PT. Indeks.

[5] Permendiknas. 2008. Pendidikan Anak Usia Dini. Jakarta: Depdiknas.

[6] Ramli, M. 2005. Pendampingan Perkembangan Anak Usia Dini. Jakarta: Depdiknas.

[7] Rusman. 2011. Model-Model Pembelajaran: Mengembangkan Guru Profesional. Jakarta: PT Rajagrafindo Persada.

[8] Saputra, Yudha M. \& Rudyanto. 2005. Pembelajaran Kooperatif untuk Meningkatkan Keterampilan Anak TK. Jakarta: Depdiknas.

[9] Suyanto, Slamet. 2005. Dasar-Dasar Pendidikan Anak UsiaDini. Yogyakarta: Hikayat Publishing.

[10] Triyono. 2005. Pintu-Pintu Pendidikan Kontekstual Anak Usia Dini. Jakarta: Depdiknas. 